\title{
OCORRÊNCIA DE LESÕES INDICATIVAS DE BRUCELOSE E TUBERCULOSE EM FÍGADO, LÍNGUA E PULMÃO DE BOVINOS ABATIDOS SOB INSPEÇÃO FEDERAL NO MUNICIPIO DE ARAGUARI, MINAS GERAIS
}

\author{
OCCURRENCE OF INDICATIVE LESIONS OF BRUCELOSIS AND TUBERCULOSIS \\ IN LIVER, TONGUE AND LUNG IN CATTLE SLAUGHTERED UNDER FEDERAL \\ INSPECTION IN MUNICIPALITY OF ARAGUARI, \\ MINAS GERAIS STATE
}

K. F. LIMA ${ }^{1 *}$, W. M. R. SOUSA ${ }^{1}$, R. F.VIEIRA ${ }^{1}$, D. P. NUNES ${ }^{2}$, R. Q. MOREIRA ${ }^{3}$

\section{RESUMO}

Objetivou-se verificar a ocorrência de lesões hepáticas, linguais e pulmonares indicativas de brucelose e tuberculose bovina em um abatedouro-frigorífico com Serviço de Inspeção Federal (SIF) localizado no município de Araguari - MG. Para isso foi feito um estudo retrospectivo da presença de lesões indicativas de brucelose e tuberculose nos órgãos fígado, língua e pulmão de 71.765 bovinos abatidos em todo o ano de 2014. O levantamento dos dados foi feito a partir de todos os registros do Departamento de Inspeção Final (DIF) do abatedouro-frigorífico, contabilizando os números de lesões por mês, e posteriormente o total daquele ano. Para as lesões de brucelose, consideraram-se as informações de diagnóstico positivo para esta doença na Guia de Trânsito Animal (GTA). Em apenas três animais (0,004\%), entre os 71.765 bovinos abatidos no período estudado, foram identificadas lesões indicativas de brucelose no fígado, na língua e nos pulmões. Para as lesões indicativas de tuberculose, foi encontrada uma frequência de 109 bovinos $(0,15 \%)$ com lesões no fígado, na língua e nos pulmões. Além desses casos, foi observado mais um bovino que apresentava tuberculose miliar. Portanto, conclui-se uma ocorrência de lesões indicativas de brucelose e tuberculose entre os bovinos abatidos no ano de $2014 \mathrm{em}$ um abatedouro-frigorífico com Serviço de Inspeção Federal (SIF) do município de Araguari - MG, representando risco à saúde pública, visto que há indícios da ocorrência destas duas zoonoses, mesmo que em uma baixa frequência de casos.

PALAVRAS-CHAVE: ZOONOSE. ABATEDOURO. Brucella abortus. Mycobacterium bovis. CONDENAÇÃO POST-MORTEM.

ÁREA TEMÁTICA: Higiene e Inspeção de Produtos de Origem Animal 